\title{
Preferential 5-Methylcytosine Oxidation in the Linker Region of Reconstituted Positioned Nucleosomes by Tet1 Protein
}

\section{$\operatorname{AUTHOR}(\mathrm{S}):$}

Kizaki, Seiichiro; Zou, Tingting; Li, Yue; Han, Yong Woon; Suzuki, Yuki; Harada, Yoshie; Sugiyama, Hiroshi

\section{CITATION:}

Kizaki, Seiichiro ...[et al]. Preferential 5-Methylcytosine Oxidation in the Linker Region of Reconstituted Positioned Nucleosomes by Tet1 Protein. Chemistry - A European Journal 2016, 22: 16598-16601

\section{ISSUE DATE:}

2016-11-07

URL:

http://hdl.handle.net/2433/230881

\section{RIGHT:}

This is the accepted version of the following article: [Seiichiro Kizaki, Tingting Zou, Yue Li, Yong - Woon Han, Yuki Suzuki, Yoshie Harada, Hiroshi Sugiyama. Preferential 5 - Methylcytosine Oxidation in the Linker Region of

Reconstituted Positioned Nucleosomes by Tet1 Protein. ChemBioChem (2016), 22, 46, 16598-16601], which has been published in final form at https://doi.org/10.1002/chem.201602435. This article may be used for non-commercial purposes in accordance with Wiley Terms and Conditions for Self-Archiving.; The full-text file will be made open to the public on 02 November 2017 in accordance with publisher's 'Terms and Conditions for Self-Archiving'.: This is not the published version. Please cite only the published version.; この論文は出版社版でありません。引用の際には出版社版 をご確認ご利用ください。 


\title{
Preferential 5-methylcytosine oxidation in the linker region of reconstituted positioned nucleosomes by Tet1 protein
}

\author{
Seiichiro Kizaki, ${ }^{[\mathrm{a}]}$ Tingting Zou, ${ }^{[\mathrm{a}]}$ Yue Li, ${ }^{[\mathrm{a}]}$ Yong-Woon Han, ${ }^{[\mathrm{b}]}$ Yuki Suzuki,${ }^{[\mathrm{b}]}$ Yoshie Harada, ${ }^{[\mathrm{b}]}$ and Hiroshi \\ Sugiyama* ${ }^{* a, b]}$
}

\begin{abstract}
Tet (ten-eleven translocation) family proteins oxidize 5methylcytosine $(\mathrm{mC})$ to 5-hydroxymethylcytosine (hmC), 5formylcytosine $(\mathrm{fC})$, and 5-carboxycytosine $(\mathrm{caC})$, and are suggested to be involved in the active DNA demethylation pathway. In this study, we reconstituted positioned mononucleosomes using CpGmethylated 382 bp DNA containing the Widom 601 sequence and recombinant histone octamer, and subjected the nucleosome to treatment with Tet1 protein. The sites of oxidized methylcytosine were identified by bisulfite sequencing. We found that, for the oxidation reaction, Tet1 protein prefers $\mathrm{mCs}$ located in the linker region of the nucleosome compared with those located in the core region.
\end{abstract}

\section{Introduction}

In eukaryotic cells, the nucleosome is the fundamental unit of chromatin. The nucleosome is formed by wrapping 146 bp of DNA around a histone octamer comprising two pairs each of $\mathrm{H} 2 \mathrm{~A}, \mathrm{H} 2 \mathrm{~B}, \mathrm{H} 3$, and $\mathrm{H} 4$. The nucleosome is the central site for the epigenetic regulation of gene expression, and histone modifications on nucleosomes affect the level of gene expression. In the nucleosome, DNA is wrapped in $\sim 1.75$ turns around the histone octamer. ${ }^{[1]}$

Many studies have reported on the chemical and biological reactions with DNA in reconstituted nucleosomes. For example, Dervan et al. investigated the DNA-binding ability of pyrroleimidazole polyamide, a DNA sequence-selective minor groovebinding molecule, with nucleosomal DNA, and discovered that polyamide can bind to nucleosomal DNA facing away from or even partially facing the histone octamer. ${ }^{[2]}$ Trzupek et al. compared the alkylation properties of yatakemycin and duocarmycin SA, which bind to the minor groove of DNA and alkylate adenine in free and nucleosomal DNA. Both compounds showed a relatively unaltered ability to alkylate nucleosomal DNA in terms of both the alkylating efficiency and sequence

[a] S. Kizaki, T. Zou, Dr. Y. Li, Dr. Y. Suzuki, Prof. Dr. H. Sugiyama Department of Chemistry, Kyoto University

Kitashirakawa-Oiwake-cho, Sakyo-ku, Kyoto-shi, Kyoto, 606-8502 (Japan)

E-mail: hs@kuchem.kyoto-u.ac.jp

[b] Dr. Y. Han, Prof. Dr. Y. Harada, Prof. Dr. H. Sugiyama Institute for Integrated Cell-Material Sciences (iCeMS), Kyoto University

Yoshida-ushinomiyacho, Sakyo-ku, Kyoto-shi, Kyoto, 606-8501 (Japan)

Supporting information for this article is given via a link at the end of the document. selectivity. ${ }^{[3]}$ By contrast, Zou et al. recently reported that duocarmycin $B_{2}$ preferentially alkylates linker DNA over core DNA. ${ }^{[4]}$

The presence of a histone octamer prevents access of proteins to DNA and hinders the access of transcriptional regulatory factors and elongating polymerase to DNA, hence controlling the process of gene expression. ${ }^{[5-8]}$ Using reconstituted nucleosomes, Takeshima et al. compared the activities of two mammalian de novo DNA methyltransferases, Dnmt3a and Dnmt3b, and found that Dnmt3a had higher DNA methylation activity than Dnmt3b toward the linker DNA region. Dnmt3a scarcely methylated the core DNA region, whereas Dnmt3b significantly methylated this region, although the activity was low. ${ }^{[9]}$

Tet (ten-eleven translocation) family proteins can oxidize 5methylcytosine $(\mathrm{mC})$ to 5-hydroxymethylcytosine $(\mathrm{hmC})$ and further to 5-formylcytosine (fC) and 5-carboxycytosine (caC) ${ }^{[10-}$ ${ }^{12]} 5$-hydroxymethylcytosine is prevalent in mouse stem cells ${ }^{[10,13]}$ and the central nervous system (CNS). ${ }^{[14]} 5$-formylcytosine and $\mathrm{caC}$ are also found in stem cells and in some organs. ${ }^{[11,15]} \mathrm{A}$ number of methods to detect and sequence $\mathrm{mC}^{[16,17]}, \mathrm{hmC}^{[18-23]}$, $\mathrm{fC}^{[24-29]}$, and $\mathrm{caC}^{[30]}$ are reported. Previously, we evaluated the effects of $\mathrm{mC}$ and $\mathrm{hmC}$ on nucleosome structure and found that replacing $\mathrm{mC}$ with $\mathrm{hmC}$ slightly relieves the packing of the nucleosome. ${ }^{[31]}$ Tet proteins are suggested to play important roles in the reprogramming of somatic cells to generate induced pluripotent stem cells (iPSCs). ${ }^{[32,33]}$ We also investigated the DNA sequence selectivity of Tet protein and showed that $\mathrm{mC}$ in the CpG sequence is most easily oxidized by Tet protein. ${ }^{[34]}$ However, it remains unknown how the nucleosome affects the activity of Tet proteins. Here we evaluated the activity of Tet1 protein in reconstituted mononucleosomes.

Plasmid containing 601 sequence (pGEM-3z/601)

$$
\text { PCR }
$$

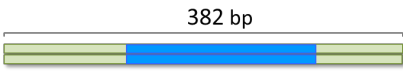

125 bp 601 sequence (146 bp) 111 bp

CpG methylation $\Omega$ M. Sssl

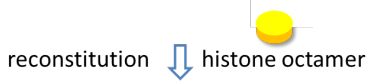
nucleosome

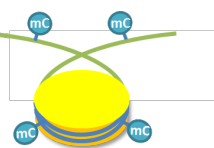

Tet treatment bisulfite sequencing $\Omega$

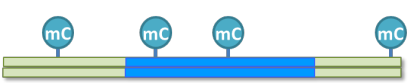

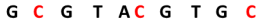

Figure 1. Preparation of CpG methylated nucleosome, followed by Tet treatment and bisulfite sequencing. 


\section{Results and discussion}

Generally, nucleosome positioning is heterogeneous, and histone octamer sliding and repositioning after nucleosome reconstitution can complicate experiments. ${ }^{[35,36]}$ In the present study, we used PCR to prepare 382 bp DNA containing the Widom 601 sequence, ${ }^{[37]}$ which provided a well-positioned mononucleosome with core and linker DNA regions.

5' ATTTAGGTGACACTATAGAATACTCAAGCTTGCATGCCTGCAGGTCCGGGATCCTAAT
3' TAAATCCACTGTGATATCTTATGAGTTCGAACGTACGGACGTCCAGGCCCTAGGATTA

GACCAAGGAAAGCATGATTCTTCCACCGAGTTCATCCCTTATGTGATGGACCCTATACGC CTGGTTCCTTTCGTACTAAGAAGGTGGCTCAAGTAGGGAATACACTACCTGGGATATGCG

GGCCGCCCTGGAGAATCCCGGTGCCGAGGCCGCTCAATTGGTCGTAGACAGCTCTAGCAC CCGGCGGGACCTCTTAGGGCCACGGCTCCGGCGAGTTAACCAGCATCTGTCGAGATCGTG

CGCTTAAACGCACGTACGCGCTGTCCCCCGCGTTTTAACCGCCAAGGGGATTACTCCCTA GCGAATTTGCGTGCATGCGCGACAGGGGGCGCAAAATTGGCGGTTCCCCTAATGAGGGAT

GTTCCAGGCACGTGTCAGATATATACATCCTGTGCATGTATTGAACAGCGACCTTGCCGG CAAGGTCCGTGCACAGTCTATATATGTAGGACACGTACATAACTTGTC GCTGGAACG

TGCCAGTCGGATAGTGTTCCGGCTCCCGACTCTAGAGGATCCCCGGGTACCGAGCTCGAA ACGGTCAGCCTATCACAAGGCCGAGGGCTGAGATCTCCTAGGGGCCCATGGCTCGAGCTT

TTCGCCCTATAGTGAGTCGTATTA3

AAGCGGGATATCACTCAGCATAAT $5^{\prime}$

Figure 2. All CpG sites of $\mathbf{3 8 2}$ bp DNA were methylated with M.SssI. Bold regions are core DNA and the other parts are linker DNA. CpG sites are underlined and shown in red

A total of $28 \mathrm{CpG}$ sites were methylated using prokaryotic DNA methyltransferase (M.SssI) (Figs 1,2). We conducted bisulfite sequencing to confirm that all cytosines on CpG sites were methylated in the 382 bp DNA fragment (Supplementary Fig. 1). ${ }^{[38,39]}$ The nucleosome was then reconstituted using the "salt-jump" dialysis method. ${ }^{[40-42]}$ After dialysis, the formation of the nucleosome was confirmed using a gel mobility shift assay (Supplementary Fig. 2-4) and atomic force microscopy (AFM) observation (Supplementary Fig. 5). Densitometric analysis of the gel mobility shift assay demonstrated that $\sim 96 \%$ of the reconstituted nucleosome was obtained.

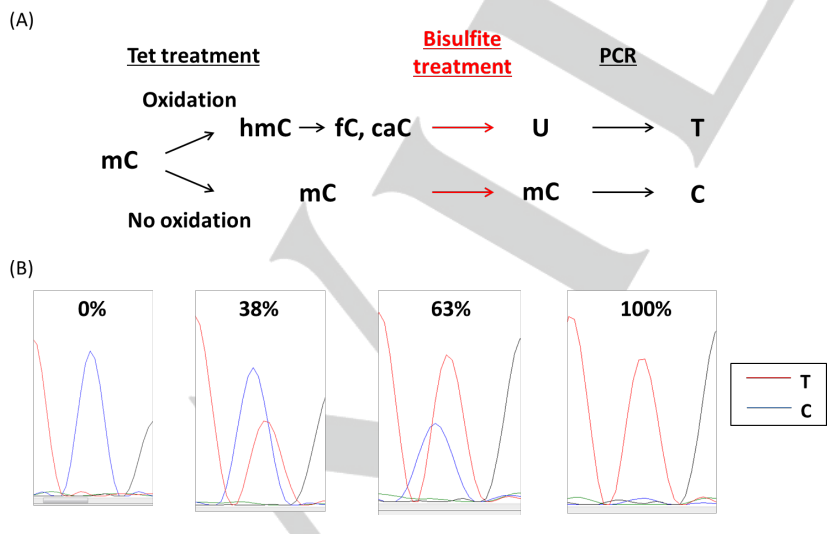

Figure 3. Bisulfite treatment of DNA. (A) $\mathrm{fC}$ and $\mathrm{caC}$ are converted to uracil by sodium bisulfite treatment, although $\mathrm{mC}$ and $\mathrm{hmC}$ do not react with sodium bisulfite. (B) Examples of the quantification of the formed $\mathrm{fC}$ and $\mathrm{caC}$. The percentages of formed $\mathrm{fC}$ and $\mathrm{caC}$ were calculated based on the area of the two peaks (blue: cytosine, red: thymine).
The reconstituted nucleosome was treated with mTet1 protein (catalytic domain) for 1 hour at $37{ }^{\circ} \mathrm{C}$, and the Tet-treated nucleosome was subjected directly to bisulfite treatment. A previous report suggested that $\mathrm{mC}$ is converted to $\mathrm{fC}$ and $\mathrm{caC}$ under this condition. ${ }^{[43]}$ Because $\mathrm{fC}$ and $\mathrm{caC}$ are converted to uracil after bisulfite treatment and read as thymine (Fig. $3 \mathrm{~A}),{ }^{[22,29,44]}$ it is possible to estimate the degree of oxidation of $\mathrm{mC}$ in a concentration-dependent manner (Fig. 3B). Using chromatograms of capillary sequencing, we estimated the percentages of formed $\mathrm{fC}$ and caC (Fig. 4 and Supplementary Fig. 6). At the core DNA region the percentages were lower than $20 \%$ (except for site6), and at the linker region the percentages were higher than $40 \%$ (Fig. 4B). Free DNA was treated with mTet1 under the same conditions and using the same concentration of mTet1 protein. However, no striking reactivity difference between core DNA region and linker DNA region was observed. This suggests that, when on the nucleosome, Tet protein prefers to oxidize $\mathrm{mCs}$ located in the linker DNA region compared with those located in the core DNA region. The bulky nucleosome core may hinder the access of Tet protein to $\mathrm{mCs}$ in the core DNA region.

(A)

5' ATTTAGGTGACACTATAGAATACTCAAGCTTGCATGCCTGCAGGTCCGGGATCCTAAT 3'TAAATCCACTGTGATATCTTATGAGTTCGAACGTACGGACGTCCAGGCCCTAGGATTA

$$
\begin{array}{cc}
\text { Site } \\
2
\end{array}
$$

GACCAAGGAAAGCATGATTCTTCCACCGAGTTCATCCCTTATGTGATGGACCCTATACGC

CTGGTTCCTTTCGTACTAAGAAGGTGGCTCAAGTAGGGAATACACTACCTGGGATATGCG

Site Site Site Site Site Site

$\begin{array}{lllll}4 & 5 & 6 & 7 & 9 \\ & 6 & 7 & 9\end{array}$

CCGGCGGGACCTCTTAGGGCCACGGCTCCGGCGAGTTAACCAGCATCTGTCGAGATCGTG

Site Site Site Site Site Site Site Site

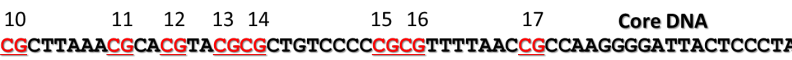
GCGAATTTGCGTGCATGCGCGACAGGGGGCGCAAAATTGGCGGTTCCCCTAATGAGGGAT Site

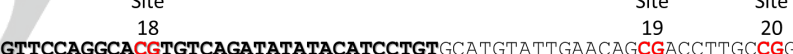

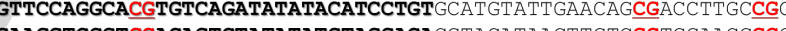
CAAGGTCCGTGCACAGTCTATATATGTAGGACACGTACATAACTTGTCGCTGGAACGGCC Site Site Site Site Site site

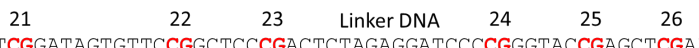
TGCCAGTCGGATAG ACGGTCAGCCTATCACAAGGCCGAGGGCTGAGATCTCCTAGGGGCCCATGGCTCGAGCTT Site Site

2728 TTCGCCCTATAGTGAGTCGTATTA3'

AAGCGGGATATCACTCAGCATAAT5

(B)

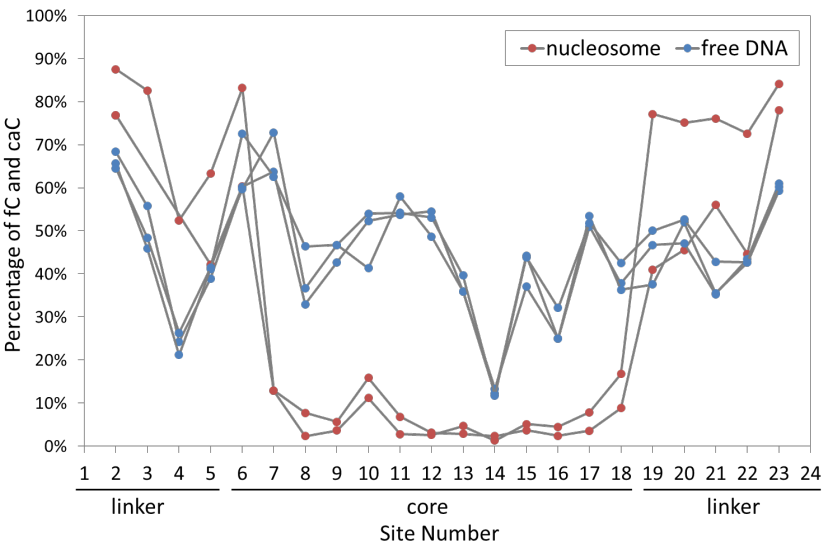

Figure 4. Quantification of $m C$ oxidation by Tet protein. (A) Sequence of DNA (B) Conversion percentage for each site in top strand DNA. Free DNA and nucleosomes were treated with $3.31 \mathrm{\mu M}$ Tet protein. 


\section{Conclusions}

We found a significant difference in the activity of Tet proteins toward $\mathrm{mCs}$ located in the core and linker DNA regions. In cells, the activity of Tet protein should be stringently regulated. The inefficient oxidation by Tet protein of the core DNA region may be important for preventing aberrant DNA demethylation. During the reprograming process, $\mathrm{mCs}$ in $\mathrm{CpG}$ islands are demethylated in a wide region of the genome. ${ }^{[45]}$ The assistance of chromatin remodeling factors to enable the access of Tet protein to DNA seems essential to this process.

\section{Experimental Section}

\section{1) mTet1 and its oxidative substrate DNA preparation:}

mTet1 active domain (1367-2039) was purchased from Wisegene (USA), stocked in $20 \mathrm{mM}$ HEPES (pH 7.4), NaCl 50 $\mathrm{mM}$, glycerol $50 \%$.

The 382 bp DNA fragment containing Widom 601 sequence was amplified by PCR using forward 5'dATTTAGGTGACACTATAGAATAC-3' and reverse 5'dTAATACGACTCACTATAGG-3' primers from pGEM-3z/601. After the reaction, the amplified DNA was purified using GenElute PCR Clean-Up Kit (Sigma-Aldrich, St. Louis, MO, USA). Then the DNA was treated with M.Sssl (New England Biolabs, Ipswich, MA, USA).

\section{2) Nucleosome reconstitution:}

CpG-methylated 382 bp DNA (200 nM) and recombinant human histone octamer (EpiCypher, Davis Dr, Durham, NC, USA) $(300 \mathrm{nM})$ were mixed together in $2 \mathrm{M} \mathrm{NaCl}$ and $20 \mathrm{mM}$ HEPES KOH (pH 7.5) (total volume $50 \mu \mathrm{L}$ ), and placed in Oscillatory Cup (MWCO: 8,000) (COSMO BIO, Tokyo, Japan). The dialysis tube was immersed into $500 \mathrm{~mL}$ of $2 \mathrm{M} \mathrm{NaCl}$ and $20 \mathrm{mM}$ HEPES KOH (pH 7.5) for 2 hours at $4{ }^{\circ} \mathrm{C}$, followed by $1.5 \mathrm{M} \mathrm{NaCl}$ (overnight), $1.0 \mathrm{M} \mathrm{NaCl}$ (8 hours), $0.75 \mathrm{M} \mathrm{NaCl}$ (overnight), and $0 \mathrm{M} \mathrm{NaCl}$ (8 hours) (each contains $20 \mathrm{mM}$ HEPES KOH ( $\mathrm{pH} 7.5)$ ). After dialysis, the sample was collected from the tube and stored at $4{ }^{\circ} \mathrm{C}$ until use.

\section{3) mTet1 oxidation and bisulfite sequencing:}

The reconstituted nucleosome $(14 \mathrm{nM})$ and $\mathrm{CpG}$-methylated 382 bp DNA (14 nM) were incubated with $3.31 \mu \mathrm{M}$ of mTet1 protein in $50 \mathrm{mM}$ HEPES ( $\mathrm{pH} 8.0$ ), $100 \mathrm{mM} \mathrm{NaCl}, 2 \mathrm{mM} \mathrm{L}$ ascorbic acid, $1 \mathrm{mM}$ 2-oxoglutarate disodium salt hydrate, 105 $\mu \mathrm{M} \mathrm{Fe}\left(\mathrm{NH}_{4}\right)_{2}\left(\mathrm{SO}_{4}\right)_{2} 6 \mathrm{H}_{2} \mathrm{O}, 1.2 \mathrm{mM}$ ATP and $2.5 \mathrm{mM}$ DTT at $37{ }^{\circ} \mathrm{C}$ for 1 hour in $20 \mu \mathrm{L}$ of reaction. Then the samples were treated with sodium bisulfite using EpiTect Bisulfite Kit (QIAGEN, Hilden, Germany). After bisulfite treatment, PCR amplification was carried out using four different PCR primersets (primer-set1: forward 5'dATAGAATATTTAAGTTTGTATGTTTGTAGG-3' and reverse 5'-dTAAAACTAAAAAATAATCCCCTTAAC-3', primer-set2: forward 5'-dGTTTAATTGGTYGTAGATAGTTTTAGTAT-3' and reverse 5'-dATACCCRAAAATCCTCTAAAATC-3', primer-set3: forward 5'-dGGTATTYGGGGATTTTTTAGAGT-3' and reverse 5'-dCTCAATTAATCRTAAACAACTCTAACACC-3' primer-set4: forward 5'- dTGTTTGGAATTAGGGAGTAATTTTTT-3' and reverse 5'- dCAAAAAAAACATAATTCTTCCACC-3' primers). After the reaction, DNA was purified using Wizard $B$ SV Gel and PCR Clean-Up System (Promega, Madison, WI, USA). Cycle sequencing was carried out with BigDye ${ }^{\circledR}$ Terminator Kit (Applied Biosytems, Foster City, CA, USA). 3130 Genetic Analyzer (Applied Biosystems) was used for sequencing. The chromatographic images were imported into ImageJ (http://rsb.info.nih.gov/ij/) and analyzed.

\section{4) AFM imaging:}

The reconstituted nucleosome was diluted to a concentration of $0.5 \mathrm{ng} / \mathrm{\mu L}$ in a buffer containing $20 \mathrm{mM}$ Tris- $\mathrm{HCl}(\mathrm{pH} 7.5), 10$ $\mathrm{mM} \mathrm{MgCl} 2$, and $1 \mathrm{mM} \mathrm{EDTA}$, and $3 \mu \mathrm{L}$ of the sample was immediately deposited onto freshly cleaved mica discs $(\varphi 1.5$ $\mathrm{mm}$ ) pretreated with $0.1 \%$ (3-Aminopropyl)triethoxysilane (APTES). After 1 min incubation, the sample was rinsed with $2 \times$ $10 \mu \mathrm{L}$ washes of the buffer and then imaged in the same buffer without the drying step. The AFM experiments were performed using Nano Live Vision (RIBM, Tsukuba, Japan). The sample was imaged in buffer solution at ambient temperature with a small cantilever of dimensions $\mathrm{L} \times \mathrm{W} \times \mathrm{H}=10 \times 2 \times 0.1 \mu^{3}$ (BL-AC10EGS, Olympus, Tokyo, Japan). These cantilevers had a spring constant of $0.1-0.2 \mathrm{~N} / \mathrm{m}$ with a resonant frequency in water of $400-1000 \mathrm{kHz}$ and $320 \times 240$ pixel images were obtained at the scan rate of 0.2 frames per second.

Keywords: Tet $\cdot 5$-hydroxymethylcytosine $\cdot 5$ methylcytosine•nucleosome

\section{References}

[1] K. Luger, A. W. Mäder, R. K. Richmond, D. F. Sargent, T. J. Richmond, Nature 1997, 389, 251-60.

[2] J. M. Gottesfeld, C. Melander, R. K. Suto, H. Raviol, K. Luger, P. B. Dervan, J Mol Biol 2001, 309, 615-629.

[3] J. D. Trzupek, J. M. Gottesfeld, D. L. Boger, Nat. Chem. Biol. 2006, 2, 79-82.

[4] T. Zou, S. Kizaki, G. N. Pandian, H. Sugiyama, Chem. - A Eur. J. 2016, DOI 10.1002/chem.201600950.

[5] Y. Lorch, J. W. LaPointe, R. D. Kornberg, Cell 1987, 49, 203-210.

[6] T. Matsui, Mol Cell Biol 1987, 7, 1401-1408.

[7] J. L. Workman, R. G. Roeder, Cell 1987, 51, 613-622.

[8] J. A. Knezetic, D. S. Luse, Cell 1986, 45, 95-104.

[9] H. Takeshima, I. Suetake, H. Shimahara, K. Ura, S. I. Tate, S. Tajima, J. Biochem. 2006, 139, 503-515.

[10] M. Tahiliani, K. P. Koh, Y. Shen, W. a Pastor, H. Bandukwala, Y. Brudno, S. Agarwal, L. M. Iyer, D. R. Liu, L. Aravind, et al., Science 2009, 324, 930-5.

[11] S. Ito, L. Shen, Q. Dai, S. C. Wu, L. B. Collins, J. A. Swenberg, C. He, Y. Zhang, Science 2011, 333, 1300-3.

[12] Y. He, B.-Z. Li, Z. Li, P. Liu, Y. Wang, Q. Tang, J. Ding, Y. Jia, Z. Chen, L. Li, et al., Science 2011, 333, 1303-7. 
S. Kriaucionis, N. Heintz, Science 2009, 324, 929-30.

M. Münzel, D. Globisch, T. Brückl, M. Wagner, V. Welzmiller, S. Michalakis, M. Müller, M. Biel, T. Carell, Angew. Chem. Int. Ed. Engl. 2010, 49, 5375-7.

[15] T. Pfaffeneder, B. Hackner, M. Truß, M. Münzel, M. Müller C. a. Deiml, C. Hagemeier, T. Carell, Angew. Chemie 2011 $123,7146-7150$

[16] J. von Watzdorf, K. Leitner, A. Marx, Angew. Chem. Int. Ed. Engl. 2016, 55, 3229-32.

[17] S. Beck, V. K. Rakyan, Trends Genet. 2008, 24, 231-237.

[18] A. Okamoto, K. Sugizaki, A. Nakamura, H. Yanagisawa, S. Ikeda, Chem. Commun. (Camb). 2011, 47, 11231-3.

[19] W. a Pastor, U. J. Pape, Y. Huang, H. R. Henderson, R. Lister, M. Ko, E. M. McLoughlin, Y. Brudno, S. Mahapatra, P. Kapranov, et al., Nature 2011, 473, 394-7.

[20] J. Terragni, J. Bitinaite, Y. Zheng, S. Pradhan, Biochemistry 2012, 51, 1009-1019.

[21] C.-X. Song, T. a Clark, X.-Y. Lu, A. Kislyuk, Q. Dai, S. W. Turner, C. He, J. Korlach, Nat. Methods 2012, 9, 75-7.

[22] M. J. Booth, M. R. Branco, G. Ficz, D. Oxley, F. Krueger W. Reik, S. Balasubramanian, Science 2012, 336, 934-7.

[23] M. Yu, G. C. Hon, K. E. Szulwach, C.-X. Song, L. Zhang, A Kim, X. Li, Q. Dai, Y. Shen, B. Park, et al., Cell 2012, 149, 1368-80.

[24] W. Mao, J. Hu, T. Hong, X. Xing, S. Wang, X. Chen, X. Zhou, Org. Biomol. Chem. 2013, 11, 3568-72.

[25] T. Tian, X. Zhang, B. Fu, Y. Long, S. Peng, S. Wang, X. Zhou, X. Zhou, Chem. Commun. (Camb). 2013, 49, 996870.

[26] E.-A. Raiber, D. Beraldi, G. Ficz, H. E. Burgess, M. R. Branco, P. Murat, D. Oxley, M. J. Booth, W. Reik, S. Balasubramanian, Genome Biol. 2012, 13, R69.

C.-X. Song, K. E. Szulwach, Q. Dai, Y. Fu, S.-Q. Mao, L. Lin, C. Street, Y. Li, M. Poidevin, H. Wu, et al., Cell 2013, 153, 1-14.

[28] J. Hu, X. Xing, X. Xu, F. Wu, P. Guo, S. Yan, Z. Xu, J. Xu, X. Weng, X. Zhou, Chemistry 2013, 19, 5836-40.

[29] M. J. Booth, G. Marsico, M. Bachman, D. Beraldi, S. Balasubramanian, Nat. Chem. 2014, 6, 435-40.
[30] X. Lu, C. Song, K. Szulwach, Z. Wang, P. Weidenbacher, P. Jin, C. He, J. Am. Chem. Soc. 2013, 135, 9315-9317.

[31] S. Kizaki, Y. Suzuki, T. Takenaka, M. Endo, H. Sugiyama, Biomater. Sci. 2014, DOI 10.1039/c4bm00113c.

[32] C. a Doege, K. Inoue, T. Yamashita, D. B. Rhee, S. Travis, R. Fujita, P. Guarnieri, G. Bhagat, W. B. Vanti, A. Shih, et al., Nature 2012, 3-6.

[33] Y. Costa, J. Ding, T. W. Theunissen, F. Faiola, T. a Hore P. V Shliaha, M. Fidalgo, A. Saunders, M. Lawrence, S. Dietmann, et al., Nature 2013, DOI 10.1038/nature11925.

[34] S. Kizaki, A. Chandranan, H. Sugiyama, Chembiochem 2015, DOI 10.1002/cbic.201500646.

[35] a Flaus, K. Luger, S. Tan, T. J. Richmond, Proc. Natl. Acad. Sci. U. S. A. 1996, 93, 1370-1375.

[36] a Flaus, T. J. Richmond, J. Mol. Biol. 1998, 275, 427-441.

[37] P. T. Lowary, J. Widom, J. Mol. Biol. 1998, 276, 19-42.

[38] M. Frommer, L. E. McDonald, D. S. Millar, C. M. Collis, F. Watt, G. W. Grigg, P. L. Molloy, C. L. Paul, Proc. Natl. Acad. Sci. U. S. A. 1992, 89, 1827-31.

[39] H. Hayatsu, Y. Wataya, K. Kai, S. lida, Biochemistry 1970 , 9, 2858-65.

[40] M. Tomschik, M. A. Karymov, J. Zlatanova, S. H. Leuba Structure 2001, 9, 1201-1211.

[41] Y. Zivanovic, I. Duband-Goulet, P. Schultz, E. Stofer, P. Oudet, A. Prunell, J. Mol. Biol. 1990, 214, 479-495.

[42] Y.-W. Han, Y. Tsunaka, H. Yokota, T. Matsumoto, G. Kashiwazaki, H. Morinaga, K. Hashiya, T. Bando, H. Sugiyama, Y. Harada, Biomater. Sci. 2014, 2, 297.

[43] S. Kizaki, H. Sugiyama, Org. Biomol. Chem. 2014, 12, 104-7.

[44] M. J. Booth, T. W. B. Ost, D. Beraldi, N. M. Bell, M. R. Branco, W. Reik, S. Balasubramanian, Nat. Protoc. 2013, 8 , 1841-51.

[45] K. Takahashi, K. Tanabe, M. Ohnuki, M. Narita, T. Ichisaka, K. Tomoda, S. Yamanaka, Cell 2007, 131, 861-72. 
WILEY-VCH

\section{Entry for the Table of Contents}

\section{COMMUNICATION}

CpG-methylated mononucleosome with linker DNA was treated with Tet1 protein. The sites of oxidized methylcytosine were identified by bisulfite sequencing. The results revealed that Tet 1 protein prefers to oxidize $\mathrm{mCs}$ located in the linker region of nucleosomes compared with $\mathrm{mCs}$ located in the core region.
Seiichiro Kizaki, Tingting Zou, Yue Li, Yong-Woon Han, Yuki Suzuki, Yoshie Harada, and Hiroshi Sugiyama*

Page No. - Page No.

Preferential 5-methylcytosine oxidation in the linker region of reconstituted positioned nucleosomes by Tet1 protein 


\section{Supplementary Information}

Figure S1. Sequencing chromatograms of bisulfite-treated CpG-methylated DNA. Sequencing chromatograms obtained by capillary sequencing using (A) primer-set1 forward primer, $(B)$ primer-set2 forward primer, $(C)$ primer-set3 forward primer, and (D) primer-set4 forward primer.

(A)

-

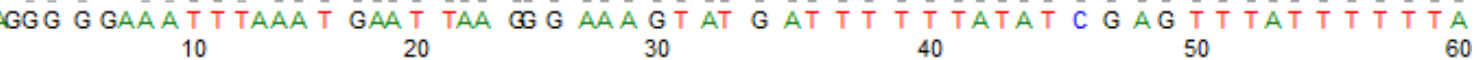

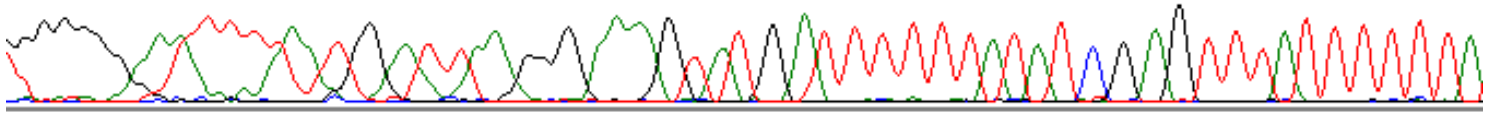

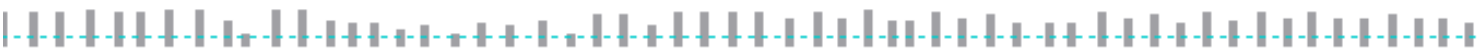

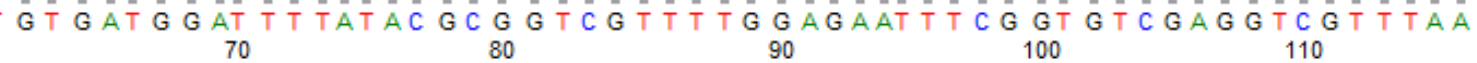

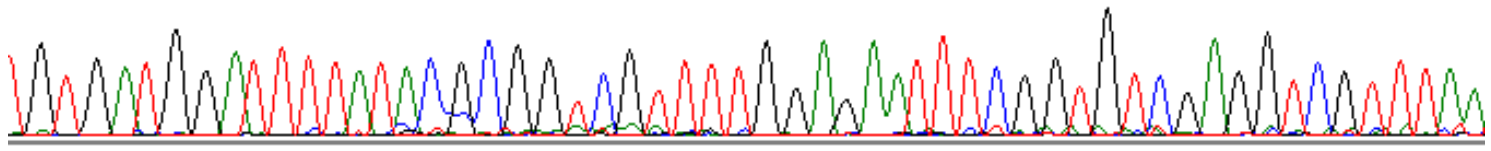

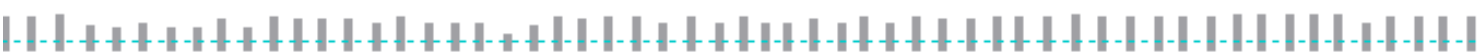

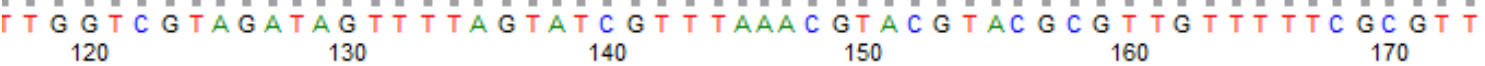

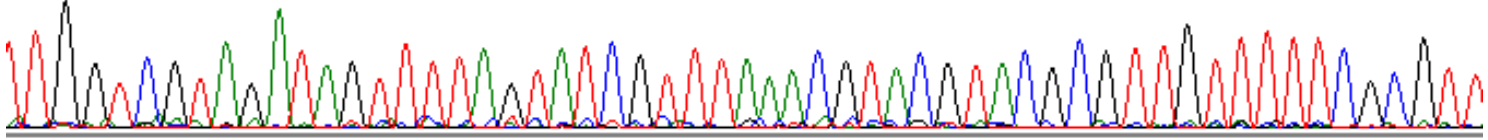

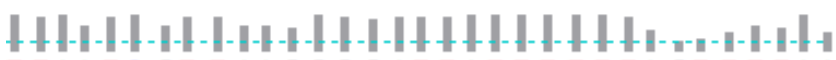
T TAATC GT TAAGGG GAT TAT T T T T TA GT T T TAA

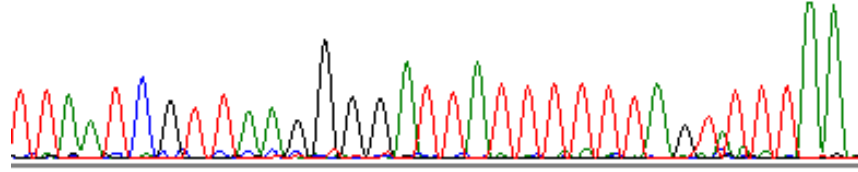


(B)

=

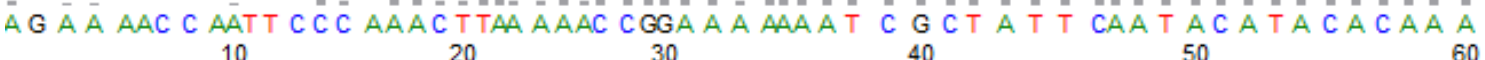
3.

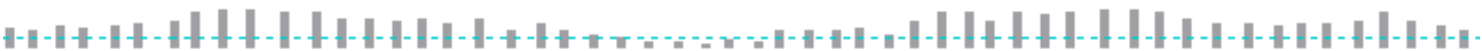

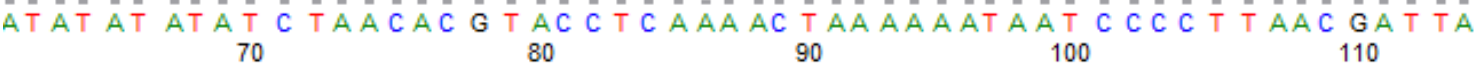

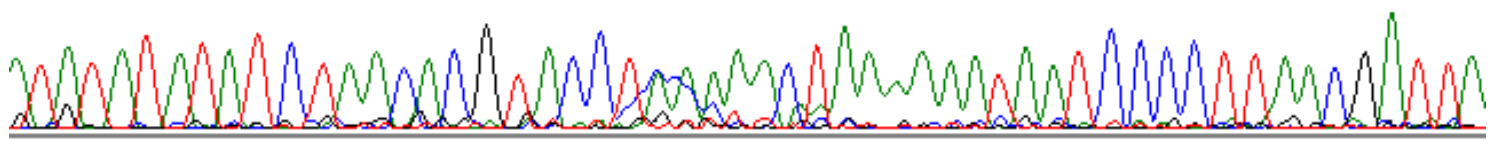

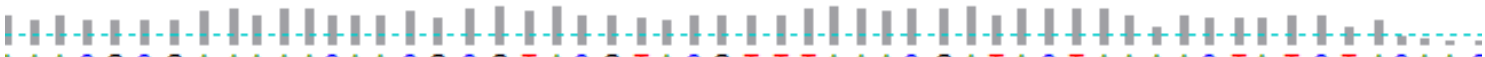

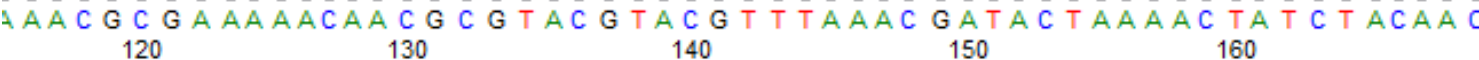

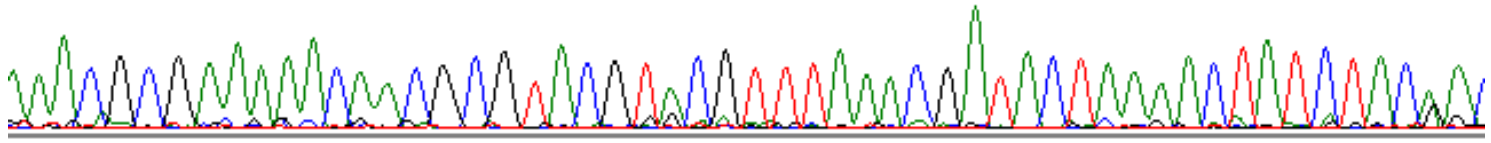

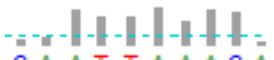
CA AT TAAACA 170

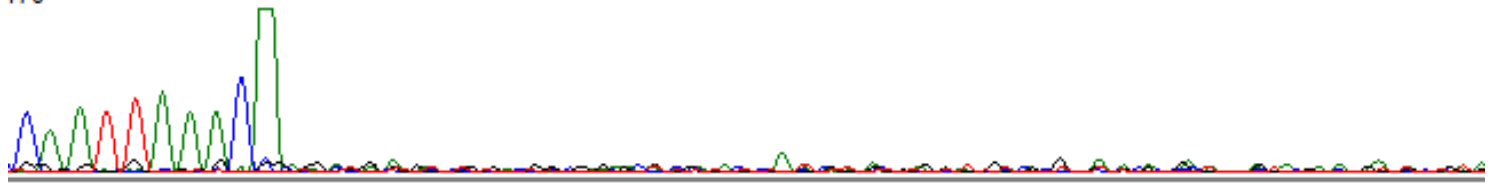


(C)

GATCC TGG ATTTATT

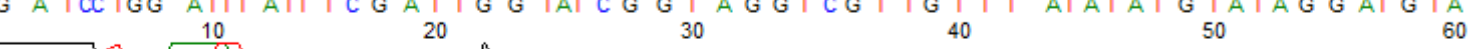

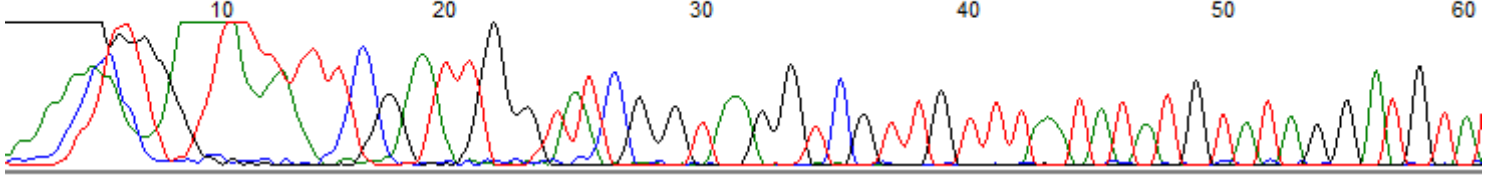

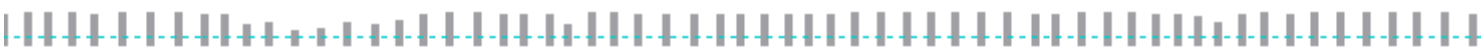

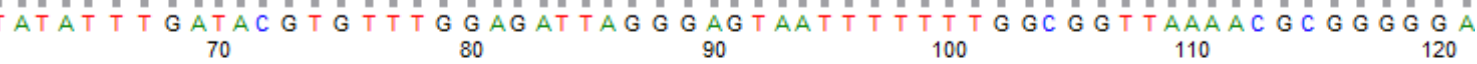

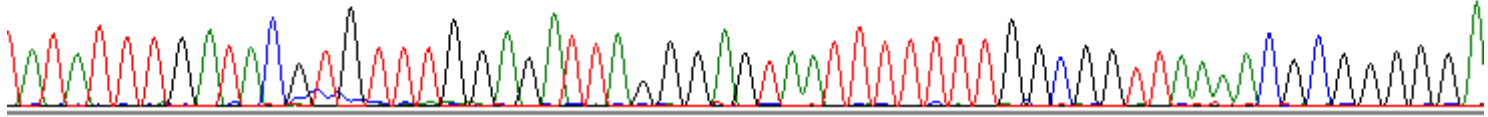

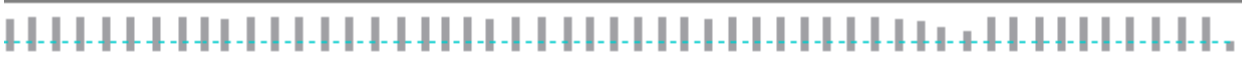

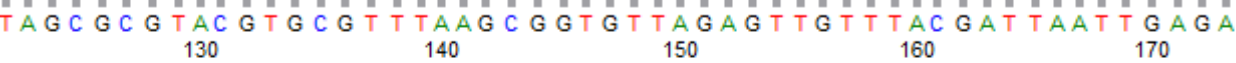

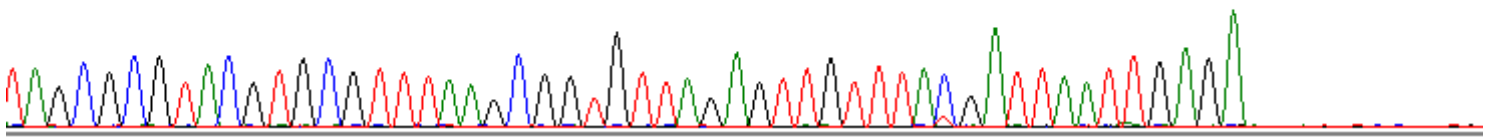

(D)

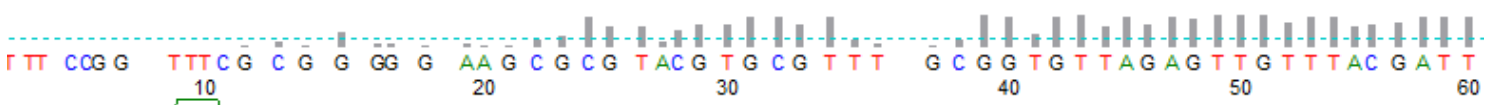

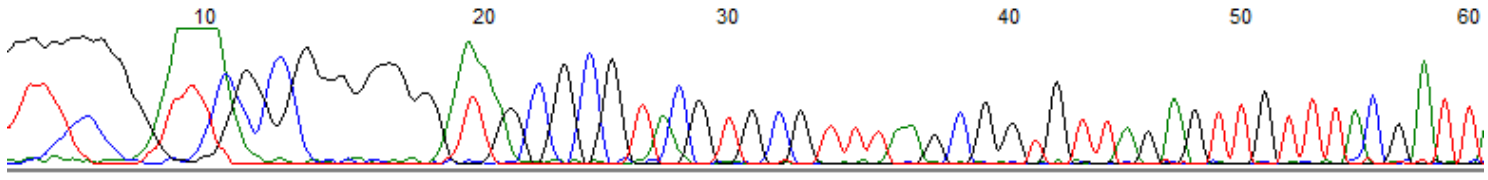

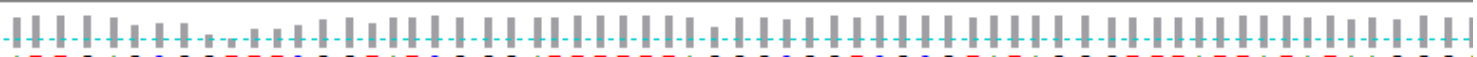
AATTGAGCGGTTTCGGTATCGGGATTTTTAGGGCGGTCGCGTATAGGGTTATTATATAAGGG

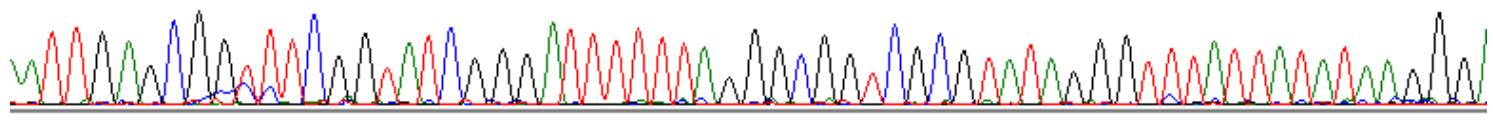

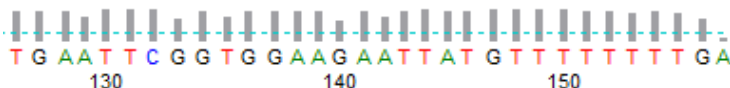

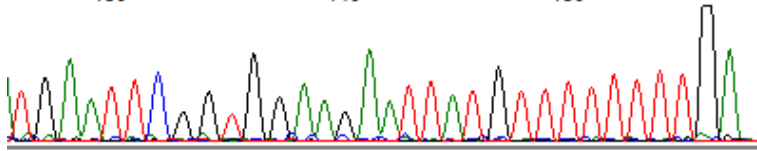


Figure S2. Gel mobility shift assay of reconstituted nucleosome. Lane 1: free DNA, Lane 2: CpG-unmethylated nucleosome, Lane 3: CpG-methylated nucleosome, 6\% polyacrylamide gel, Electrophoresis was conducted at $4{ }^{\circ} \mathrm{C}$ for 1 hour (100 V) and the gel was stained with ethidium bromide.

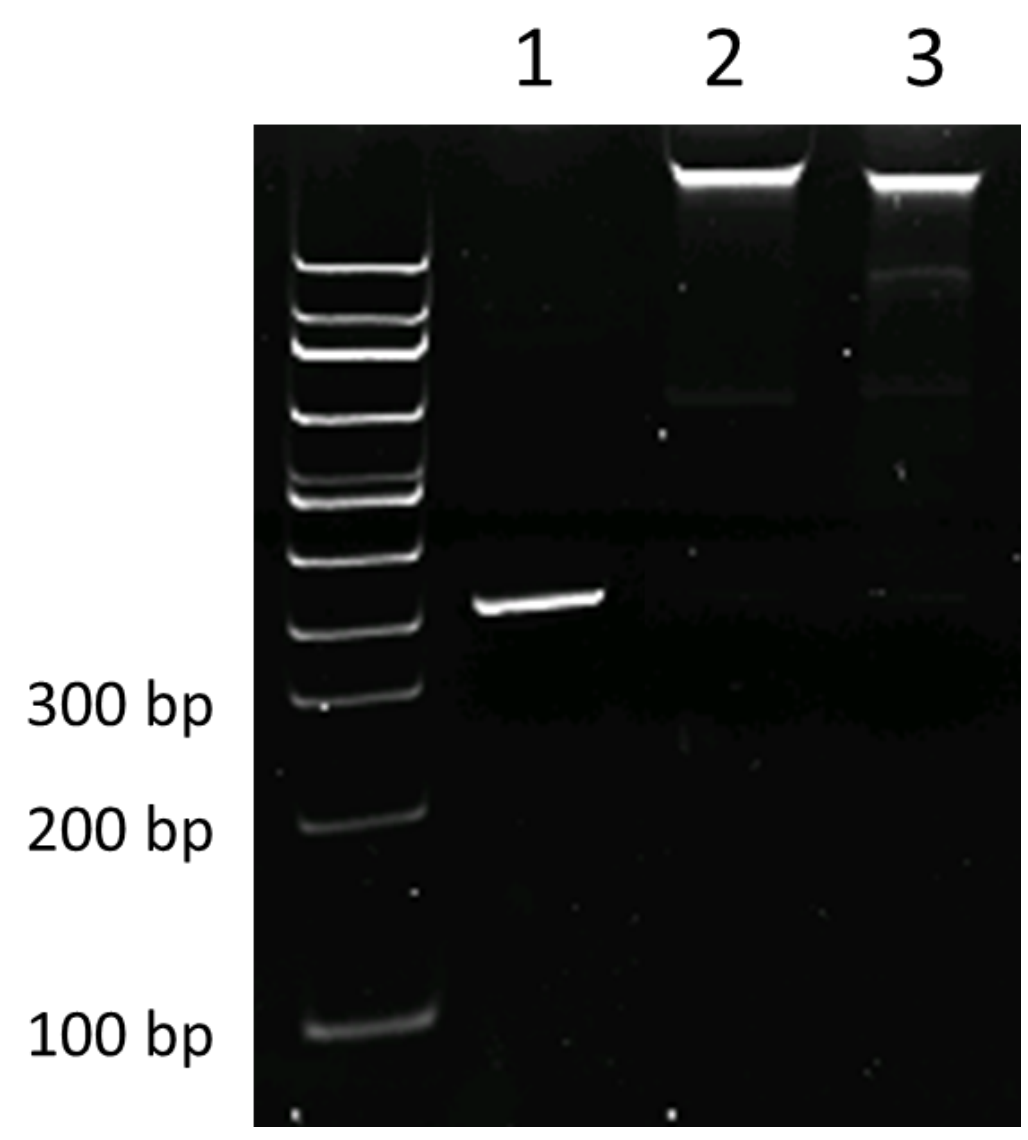


Figure S3. Gel mobility shift assay of reconstituted nucleosome. Lane 1: free DNA, Lane 2: CpG-methylated nucleosome, Lane 3: CpG-methylated nucleosome (the gel was stained with Coomassie Brilliant Blue staining solution), $6 \%$ polyacrylamide gel, Electrophoresis was conducted at $4{ }^{\circ} \mathrm{C}$ for 1 hour (100 V).

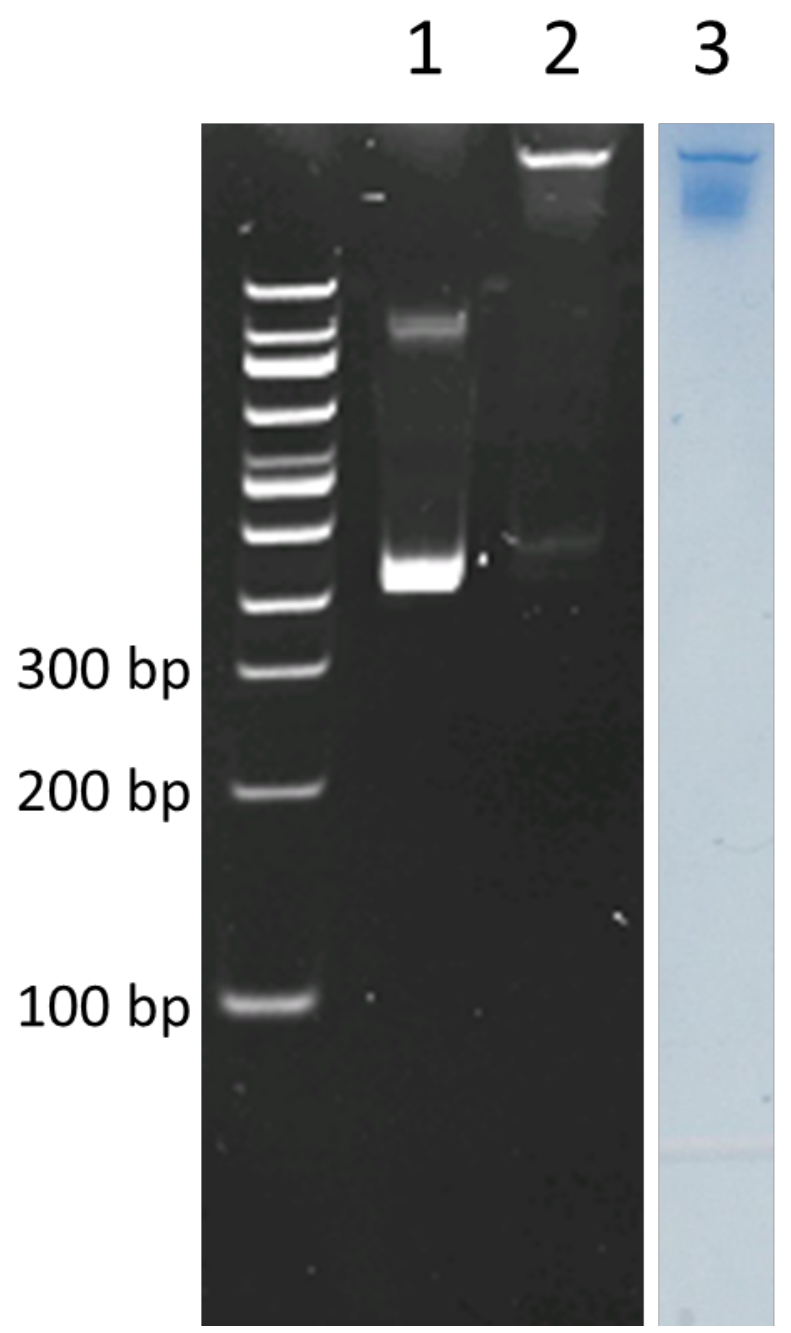


Figure S4. Nuclease digestion of reconstituted nucleosome. Lane 1: free DNA, Lane 2: CpG-methylated nucleosome, Lane 3: CpG-methylated nucleosome treated with micrococcal nuclease (NEB) at $37^{\circ} \mathrm{C}$ for $10 \mathrm{~min}, 6 \%$ polyacrylamide gel, Electrophoresis was conducted at $4{ }^{\circ} \mathrm{C}$ for 1 hour $(100 \mathrm{~V})$ and the gel was stained with ethidium bromide.

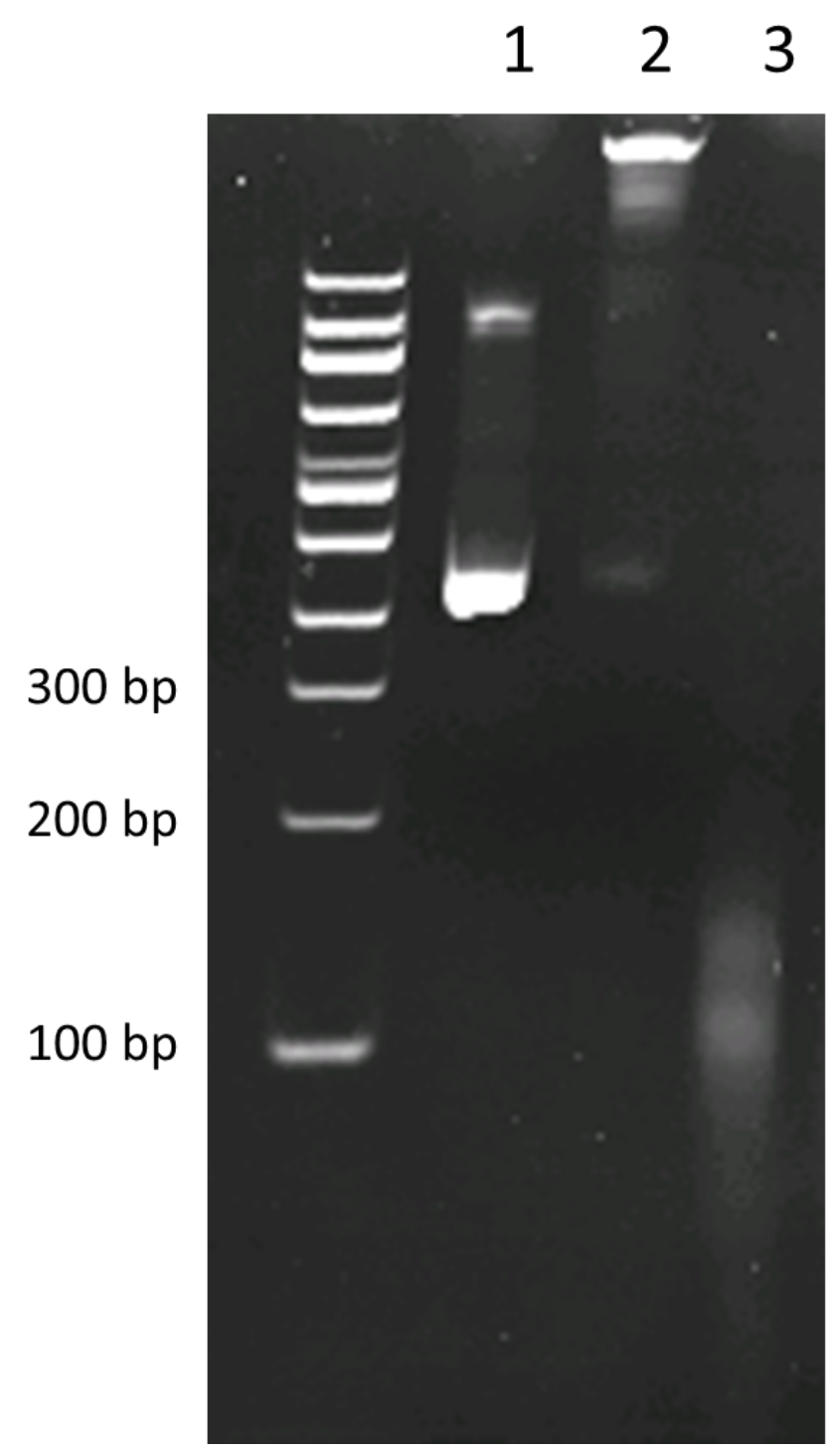


Figure S5. AFM image of reconstituted CpG-methylated nucleosome.

Reconstituted nucleosome was observed in $20 \mathrm{mM}$ Tris- $\mathrm{HCl}(\mathrm{pH}$ 7.5).

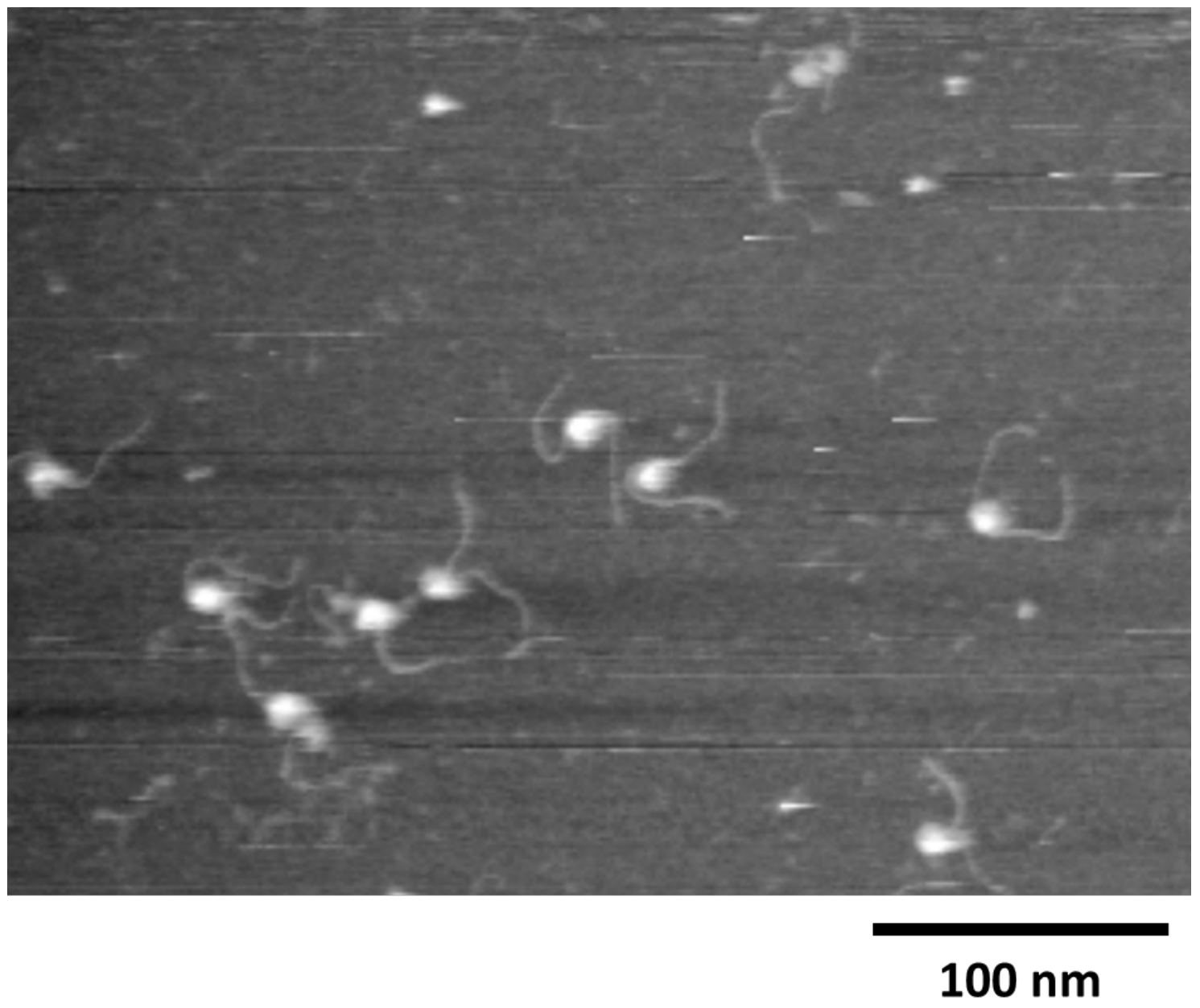


Figure S6. Quantification of $\mathrm{mC}$ oxidation by Tet protein. Conversion percentage for each site in bottom strand DNA. Free DNA and nucleosome were treated with 3.31 $\mu \mathrm{M}$ Tet protein.

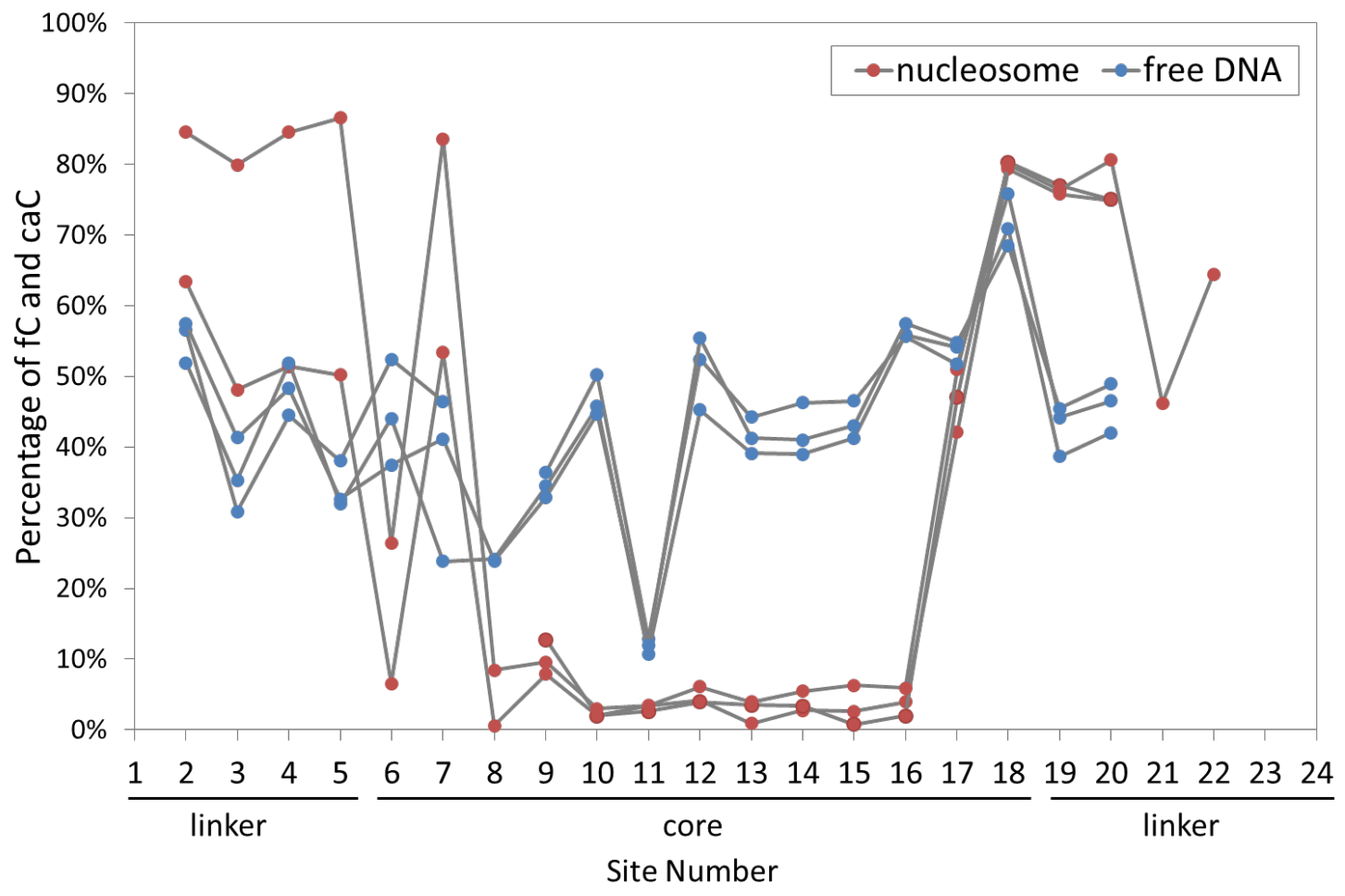

